\title{
3-Hydroxy-3-methylglutaric Aciduria: Response to Carnitine Therapy and Fat and Leucine Restriction
}

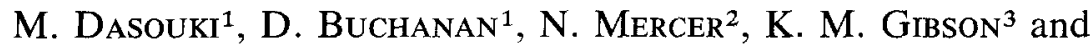 \\ J. THOENE ${ }^{1}$
}

${ }^{1}$ Department of Pediatrics and Communicable Diseases, Division of Biochemical Genetics and Metabolism; ${ }^{2}$ Department of Dietetics, Nutrition Services, University of Michigan, Ann Arbor, Michigan, USA; ${ }^{3}$ Department of Pediatrics, Division of Biochemical Genetics, University of California, San Diego, La Jolla, California, USA

\begin{abstract}
A female infant, born to first cousin parents, lapsed into coma with severe metabolic acidosis on day three of life. The gas chromatographic/mass spectrometric urinary organic acid profile showed marked elevation of the leucine metabolites 3-hydroxy-3-methylglutaric, 3-methylglutaconic, 3-methylglutaric and 3-hydroxy-isovaleric acids. Less than $5 \%$ of the normal activity of the enzyme 3-hydroxy-3-methylglutaryl CoA lyase was detected in cultured skin fibroblasts. The patient's total and free carnitine was initially low but rose to normal levels after placing her on DL-carnitine $\left(100 \mathrm{mg} \mathrm{kg}^{-1} \mathrm{~d}^{-1}\right)$. On a diet providing $87 \mathrm{mg} \mathrm{kg}^{-1} \mathrm{~d}^{-1}$ of leucine and only $25 \%$ of total calories as fat and $2 \mathrm{~g} \mathrm{~kg}^{-1} \mathrm{~d}^{-1}$ protein, the concentration of the urinary organic acids fell markedly. She is now 15 months old with normal growth and development. This regimen appears effective in the early treatment of 3-hydroxy-3methylglutaric aciduria.
\end{abstract}

3-Hydroxy-3-methylglutaric aciduria (McKusick 24645) was first described by Faull and colleagues (1976a; 1976b). Thirteen patients with this condition have been described to date. This inborn error of metabolism, which is due to deficiency of intramitochondrial 3-hydroxy-3-methylglutaryl CoA lyase (HMG-CoA lyase, EC 4.1.3.4; Clinkenbeard et al., 1975), typically presents with metabolic acidosis, hypoglycaemia, hepatomegaly, and feeding and respiratory difficulties. Leucine metabolites proximal to the site of enzymatic block accumulate and are excreted in the urine. Typically the concentrations of 3-hydroxy-3-methylglutaric, 3methylglutaconic, 3-methylglutaric and 3-hydroxyisovaleric acids are elevated in the urine (Faull et al., 1976a; 1976b). Since 3-hydroxy-3-methylglutaric acid is not cleaved into acetyl $\mathrm{CoA}$ and acetoacetic acid, the metabolic acidosis in these patients is not accompanied by ketonuria. Because of the effective renal clearance,

MS received 24.6.86. Accepted 23.10.86 
only small elevations in serum organic acids may be observed (Duran et al., 1979). Wysocki and colleagues (1976) and Wysocki and Hahnel (1976a; 1976b) documented the deficiency of the 3-hydroxy-3-methylglutaryl CoA lyase in skin fibroblasts and leukocytes. The placenta and liver were also found to have little enzymatic activity in other affected children (Duran et al., 1979; Schutgens et al., 1979; Robinson et al., 1980; Norman et al., 1982). Consanguinity and intermediate parental enzyme levels were reported in several cases (Gibson et al., 1982; Greene et al., 1984; Wilson et al., 1984), thus providing evidence for autosomal recessive inheritance.

We report another infant with this condition who responded to a low fat, low protein diet, supplemented with carnitine.

\section{CASE REPORT}

The 15-month-old girl presented on day three of life with gasping, duskiness and vomiting. On admission she had shallow, slow respirations, hypothermia $\left(34.4^{\circ} \mathrm{C}\right)$, abdominal distention and a palpable liver $(3 \mathrm{~cm}$ below the costal margin). She showed easy bruising at venipuncture sites. She was the product of a full term pregnancy and uncomplicated vaginal delivery to a 22-year-old gravida 2 parity 1 healthy Arabic woman. The parents are first cousins. The birthweight was $3.54 \mathrm{~kg}$ and Apgar scores were normal, 9 and 9 at 1 and $5 \mathrm{~min}$ respectively. At the time of admission the patient was intubated and put on a ventilator. On the second day she had a fit for which anticonvulsant therapy was initiated. Laboratory investigations included arterial blood gases which showed metabolic acidosis ( $\mathrm{pH} 7.2, \mathrm{pCO}_{2} 33$, bicarbonate 13 ), requiring intravenous infusion with sodium bicarbonate. The blood glucose was normal and urinalysis demonstrated no ketonuria. Total and direct bilirubin were 8.9 and $0.9 \mathrm{mg} \mathrm{dL}^{-1}$. The transaminases (SGOT, SGPT) and LDH were elevated $\left(640,262\right.$ and $2290 \mathrm{IU} \mathrm{L}^{-1}$ respectively). The prothrombin time was increased $(26.7 / 22 \mathrm{~s})$ and fibrinogen was decreased $\left(117 \mathrm{mg} \mathrm{dL}^{-1}\right)$. Blood ammonia $\left(233 \mu \mathrm{mol} \mathrm{L}^{-1}\right)$, lactic acid $\left(6.1 \mathrm{meq} \mathrm{L}^{-1}\right)$ and pyruvic acid $\left(2.7 \mathrm{mg} \mathrm{dL}^{-1}\right)$ were elevated. No evidence of infection was obtained and EEG and cranial ultrasound examinations were normal. Because of the history of consanguinity and the finding of non-ketotic metabolic acidosis in a comatose baby, a metabolic disease was suspected. Urinary gas chromatography/mass spectrometry analysis showed massive elevation of organic acids characteristic of 3-hydroxy-3methylglutaric aciduria (Table 1). The patient had initial plasma total and free carnitine levels of 28.9 and $7.8 \mu \mathrm{mol} \mathrm{L}^{-1}$. She was put on DL-carnitine, $100 \mathrm{mg} \mathrm{kg}^{-1} \mathrm{~d}^{-1}$, and a $2 \mathrm{~g} \mathrm{~kg}^{-1} \mathrm{~d}^{-1}$ protein diet. Her carnitine concentrations rose to 62.6 and $42.7 \mu \mathrm{mol} \mathrm{L}-1$ (total and free) after four days of therapy. The discharge formula provided a daily intake of $2 \mathrm{~g} \mathrm{~kg}^{-1}$ of protein, $87 \mathrm{mg} \mathrm{kg}^{-1}$ of leucine, $25 \%$ of total caloric intake as fat and $100 \mathrm{mg} \mathrm{kg}^{-1}$ DL-carnitine.

\section{METHODS}

The urinary organic acids were profiled by gas chromatography/mass spectrometry as the trimethylsilyl derivatives after solvent extraction (Goodman and Markey, 
1981). Selected ion monitoring mass spectrometry on an HP 5995B GC/MS using a Supelco SPB- $160 \mathrm{~m}$ 'mega bore' column was used for quantification of the urinary organic acids. The method of standard additions to a normal urine was employed to obtain a working curve for each acid which was quantified.

HMG-CoA lyase activity was determined by two methods using lysates of cultured skin fibroblasts from the patient. The direct method utilized $\left[{ }^{14} \mathrm{C}\right]-\mathrm{HMG}-$ $\mathrm{CoA}$ as a substrate using a modification of the method of Gibson and colleagues (1982), while the indirect method can detect blocks at three steps in the leucine pathway. In this coupled assay the combined activities of 3-methylcrotonyl-CoA carboxylase (EC 6.4.1.4), 3-methylglutaconyl-CoA hydratase (EC 4.2.1.18) and 3hydroxy-3-methylglutaryl-CoA lyase (EC 4.1.3.4) are determined. 3-methylcrotonyl-CoA and $\mathrm{NaH}^{14} \mathrm{CO}_{3}$ are used as substrates and exogenous 3-hydroxybutyrate dehydrogenase (EC 1.1.1.30), NADH and ATP are added. $1-\left[{ }^{14} \mathrm{C}\right]$-acetoacetic acid is converted to the stable $1-\left[{ }^{14} \mathrm{C}\right]-3$-hydroxybutyric acid. The free acids are separated and quantified by reverse phase HPLC after hydrolysis of the coenzyme A esters.

\section{RESULTS AND DISCUSSION}

Table 1 shows a marked elevation of 3-hydroxy-3-methylglutaric, 3-methylglutaconic, 3-methylglutaric and 3-hydroxyisovaleric acid excretion in the urine. 3hydroxy-3-methylglutaric acid was the major metabolite. Although newborns may normally excrete some 3-hydroxy-3-methylglutaric acid in their urine (Lippe et al.,

Table 1 Urinary organic acid excretion ( $\mu \mathrm{g} \mathrm{mg} \mathrm{creatinine}^{-1}$ )

\begin{tabular}{lcccc}
\hline Age & $\begin{array}{c}3- \\
\text { hydroxyisovaleric } \\
\text { acid }\end{array}$ & $\begin{array}{c}3- \\
\text { methylglutaric } \\
\text { acid }\end{array}$ & $\begin{array}{c}3- \\
\text { methylglutaconic } \\
\text { acid }\end{array}$ & $\begin{array}{c}\text { 3-hydroxy-3- } \\
\text { methylglutaric } \\
\text { acid }\end{array}$ \\
\hline Day 1 & 23600 & 240 & 6910 & 17800 \\
Day 9 & 0 & 0 & 360 & 827 \\
Day 15 & 170 & 130 & 914 & 2830 \\
Day 30 & 28 & 15 & 134 & 910 \\
2.5 months & 0 & 27 & 194 & 320 \\
4.5 months & 195 & 70 & 590 & 1590 \\
\hline
\end{tabular}

1982), the urinary excretion of other leucine metabolites and documentation of the enzyme deficiency established the diagnosis of 3-hydroxy-3-methylglutaric aciduria. Less than 5\% of the activity of 3-hydroxy-3-methylglutaryl-CoA lyase was detected in lysates of cultured skin fibroblasts (Table 2), and in the coupled assay there was no production of $1-\left[{ }^{14} \mathrm{C}\right]-3$-hydroxybutyric acid, thereby localizing the defect to the final step in leucine degradation.

The patient's initial plasma leucine concentration was $90 \mu \mathrm{mol} \mathrm{L}^{-1}$ (normal: $77 \pm 21$ ), and she required bicarbonate maintenance for the acidosis. Restriction of her leucine intake to $87 \mathrm{mg} \mathrm{kg}^{-1} \mathrm{~d}^{-1}$ resulted in a decrease in the abnormal urinary organic acid excretion while preserving an acceptable plasma leucine concentration.

Carnitine deficiency was found in this patient. Both total and free plasma carnitine 
Table 2 3-Hydroxy-3-methylglutaryl CoA lyase activity in cultured skin fibroblasts

\begin{tabular}{lcc}
\hline \multicolumn{1}{c}{ Subject } & $\begin{array}{c}\text { 3-hydroxy-3-methylglutaryl- } \\
\text { CoA lyase activity } \\
\left(\mathrm{pmol} \mathrm{min}^{-1} \text { mg protein }^{-1}\right)\end{array}$ & $\begin{array}{c}\text { Percentage of simultaneous } \\
\text { control }\end{array}$ \\
\hline Previous controls $(n=5)$ & $2230 \pm 1060($ mean $\pm \mathrm{SD})$ & \\
Controls $(n=3)$ & Range $1440-3750$ & 100 \\
Patient $(3$ harvests $)$ & $3840,3500,3000$ & $2.4,3.6,4.7$ \\
\hline
\end{tabular}

rose from 28.9 and $7.8 \mu \mathrm{mol} \mathrm{L}^{-1}$ to 62.6 and $42.7 \mu \mathrm{mol} \mathrm{L}^{-1}$, four days after placing her on DL-carnitine $\left(100 \mathrm{mg} \mathrm{kg}^{-1} \mathrm{~d}^{-1}\right)$. This confirms the previous findings in two patients with 3-hydroxy-3-methylglutaric aciduria reported by Chalmers and colleagues $(1984 a ; 1984 b)$. Secondary carnitine deficiency has been reported by other investigators associated with a number of inborn errors of metabolism. In 3hydroxy-3-methylglutaric aciduria, acetoacetic acid is not formed and an increased intramitochondrial acyl $\mathrm{CoA} / \mathrm{CoASH}$ results. Acyl $\mathrm{CoA}$ moieties will be conjugated with carnitine to form acyl carnitines which are excreted in the urine causing secondary carnitine deficiency (Chalmers et al., 1984a; 1984b). Symptoms of carnitine deficiency may overlap with those of Reye's syndrome and 3-hydroxy-3methylglutaric aciduria. These include vomiting, fatigue, muscle weakness and altered level of consciousness. Hepatomegaly, hypoglycaemia and elevated liver enzymes are also seen. Correction of carnitine deficiency may therefore result in clinical improvement.

Restriction of fat intake in 3-hydroxy-3-methylglutaric aciduria was reported in two patients by Berry and colleagues (1981). This should decrease the amount of acetoacetate formed, minimizing the demand on acetyl-CoA and thus reducing the inhibition of pyruvate carboxylase which controls gluconeogenesis through phosphoenolpyruvate. This patient showed marked clinical improvement after the adjustment of her diet to limit the intake of total protein $\left(2 \mathrm{~g} \mathrm{~kg}^{-1} \mathrm{~d}^{-1}\right)$, fat (25\% of total calories) and leucine ( $\left.87 \mathrm{mg} \mathrm{kg}^{-1} \mathrm{~d}^{-1}\right)$, along with carnitine supplementation.

She is currently 15 months old and has demonstrated normal growth and development for her age with only one episode of acute acidosis in the first year of life. This was readily controlled with intravenous bicarbonate.

\section{ACKNOWLEDGEMENT}

This work was supported in part by grants AM 25548 from the National Institutes of Health and C-326 from the March of Dimes, and the Michigan Department of Mental Health Genetic Screening Program.

\section{REFERENCES}

Berry, H. K., Suchy, F., Hunt, M. and Norman, E. Treatment of 3-hydroxy-3-methylglutaric aciduria in first cousins. In: Walser, M. and Williamson, J. R. (eds.), Metabolism and 
Clinical Implications of Branched Chain Amino and Ketoacids. Elsevier North Holland, 1981, pp. 405-410

Chalmers, R. A., Roe, C. R., Stacey, T. E. and Hoppel, C. L. Urinary excretion of Lcarnitine and acylcarnitines by patients with disorders of organic acid metabolism: Evidence for secondary insufficiency of L-carnitine. Pediatr. Res. 18 (1984a) 1325-1328

Chalmers, R. A., Stacey, T. E., Tracey, B. M., De Sousa, C., Roe, C. R., Millington, D. S. and Hoppel, C. L. L-Carnitine insufficiency in disorders of organic acid metabolism: Response to L-carnitine by patients with methylmalonic aciduria and 3-hydroxy-3methylglutaric aciduria. J. Inher. Metab. Dis. 7 Suppl. 2 (1984b) 109-110

Clinkenbeard, K. D., Reeds, W. D., Mooney, R. A. and Lane, M. D. Intracellular localization of the 3-hydroxy-3-methylglutaryl coenzyme A cycle enzymes in liver. $J$. Biol. Chem. 250 (1975) 3108-3116

Duran, M., Schutgens, R. B. H., Ketel, A., Heymans, H., Berntssen, M. W. J., Ketting, D. and Wadman, S. K. 3-hydroxy-3-methylglutaryl CoA lyase deficiency: Postnatal management following prenatal diagnosis by analysis of maternal urine. J. Pediatr. 95 (1979) 1004-1007

Faull, K. F., Bolton, P. D., Halpern, B., Hammond, J. and Danks, D. M. The urinary organic acid profile associated with 3-hydroxy-3-methylglutaric aciduria. Clin. Chim. Acta 73 (1976b) 553-559

Faull, K., Bolton, P. D., Halpern, B., Hammond, J., Danks, D., Hahnel, R., Wilkinson, S. P., Wysocki, S. J. and Masters, P. L. Patient with defect in leucine metabolism. $N$. Engl. J. Med. 294 (1976a) 1013

Gibson, K. M., Sweetman, L., Nyhan, W. L., Page, T. M., Greene, C. and Cann, H. M. 3-hydroxy-3-methylglutaric aciduria: a new assay of 3-hydroxy-3-methylglutaryl CoA lyase using high performance liquid chromatography. Clin. Chim. Acta 126 (1982) 171181

Goodman, S. I. and Markey, S. P. Diagnosis of Organic Acidemias by Gas ChromatographyMass Spectrometry, Liss, New York, 1981, pp. 105-106

Greene, C. L., Cann, H. M., Robinson, B. H., Gibson, K. M., Sweetman, L., Holm, J. and Nyhan, W. L. 3-hydroxy-3-methylglutaric aciduria. J. Neurogenet. 1 (1984) 165-173

Lippe, G., Galzigna, L., Francesconi, M., Zorzi, C. and Deana, R. Age-dependent excretion of 3-hydroxy-3-methylglutaric acid (HMG) and ketone bodies in the urine of full term and pre-term newborns. Clin. Chim. Acta 126 (1982) 291-295

Norman, E. J., Denton, M. D. and Berry, H. K. Gas chromatographic/mass spectrometric detection of 3-hydroxy-3-methylglutaryl CoA lyase deficiency in double first cousins. Clin. Chem. 28 (1982) 137-140

Robinson, B. H., Oei, J., Sherwood, W. G., Slyper, A. H., Heininger, J. and Mamer, O. A. Hydroxymethylglutaryl CoA lyase deficiency: Features resembling Reye syndrome. Neurology 30 (1980) 714-718

Schutgens, R. B. H., Heymans, H., Ketel, A., Veder, H. A., Duran, M., Ketting, D. and Wadman, S. K. Lethal hypoglycemia in a child with a deficiency of 3-hydroxy-3methylglutaryl CoA-lyase. J. Pediatr. 94 (1979) 89-91

Wilson, W. G., Cass, M. B., Svik, O., Gibson, K. M. and Sweetman, L. A child with acute pancreatitis and recurrent hypoglycemia due to 3-hydroxy-3-methylglutaryl CoA lyase deficiency. Eur. J. Pediatr. 142 (1984) 289-291

Wysocki, S. J. and Hahnel, R. 3-hydroxy-3-methylglutaric aciduria: Deficiency of 3-hydroxy3-methylglutaryl CoA lyase. Clin. Chim. Acta 71 (1976a) 349-351

Wysocki, S. J. and Hahnel, R. 3-hydroxy-3-methylglutaric aciduria: 3-hydroxy-3-methylglutaryl-Coenzyme A lyase levels in leukocytes. Clin. Chim. Acta 73 (1976b) 373-375

Wysocki, S. J., Wilkinson, S. P., Hahnel, R., Wong, C. Y. B. and Panegyres, P. K. 3hydroxy-3-methylglutaric aciduria, combined with 3-methylglutaconic aciduria. Clin. Chim. Acta 70 (1976) 399-406 